

\title{
RADIOCHEMICAL ANALYSES OF SAMPLES FROM BENEATH A SOLID RADIOACTIVE WASTE DISPOSAL PIT AT LOS ALAMOS, NEW MEXICO
}

by

W. D. Purtymun, M. A. Rogers, M. L. Wheeler*

\begin{abstract}
Solid radioactive wastes are disposed of by burial in pits excavated in rhyolite tuff at the Los Alamos Scientific Laboratory (LASL). Contaminant: in the waste include fission products, uranium, and traneuranic eiements. In 1976, horizontal core holes were drilled beneath a waste disposal pit that was used from 1963 to 1966 . Samples of the core were analyzed for crose alpha, gross beta, total uranium, ${ }^{20} \mathrm{Sr},{ }^{137} \mathrm{Cs}$, ${ }^{231} \mathrm{Pu},{ }^{230.240} \mathrm{Pu}$, and ${ }^{241} \mathrm{Am}$. The measured gross alpha, gross beta, and uranium concentrations were above minimum detection limits; concentrations of the remaining radionuclides, all of which are man-made isotopes, were below the minimum detection limits. Statistical comparisons were made of the cross alpha, sross beta, and uranium data to identify any significant variations from natural concentrations in the tuff. The comparicons demonstrated that none of the radioactivity detected in the samples can be attributed to migration from the disposal pit.
\end{abstract}

\section{INTRODUCTION}

Shailow land burial has been used for disposal of solid radioactive wastes at LASL since the early 1940 s. Previous studies have shown that there is little potential for migration of radionuclides from the wastes because of the geologic and hydrologic characteristics of the disposal sites. ${ }^{1,2,3}$ The purpose of this investigation was to determine whether any radionuclides have migrated downward from a waste pit used in the early $1960 \mathrm{~s}$. Horizontal core holes were drilled beneath the pit from a nearby canyon wall, and samples of the core were analyzed for radioactive constituents known to be present in the

*Authors listed in alphabetical order. pit. The results of these analyses were then compared with expected background values from noncontaminated areas.

\section{THE STUDY SITE}

\section{A. Description and Location}

The LASL technical areas (TA) are located on the Pajarito Plateau, a tcpographic high along the western side of the Rio Grance Valley in northern New Mexico. The Plateau slopes gently eastward from the base of the Sierra de los Valles to the cliffa overlooking the Rio Grande (Fig. 1). Southeast trending streams have dicsected the Plateau into 


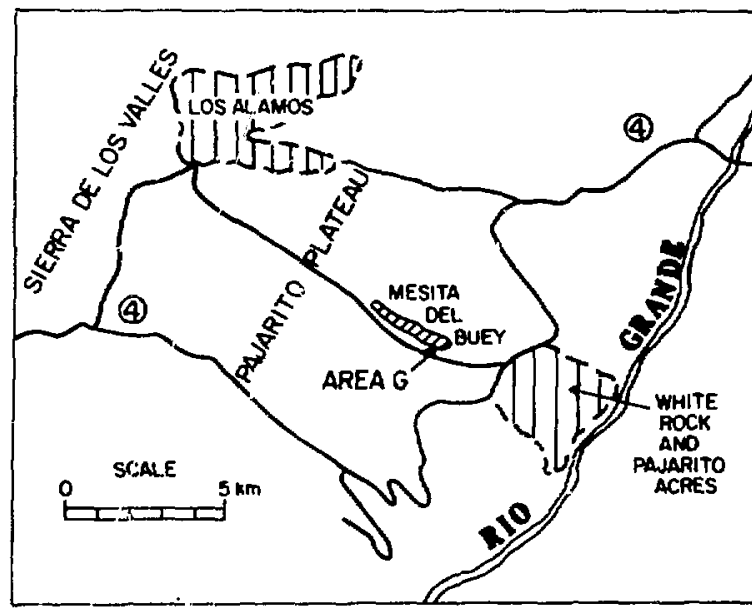

Fig. 1.

Physiographic features of the Los Alamos area showing location of Mesita del Buey.

narrow finger-like mesas. The majority of LASL's facilities, including waste disposal sites, are located on the tops of these mesas.

In 1956, Area G, TA-54, was designated for the disposal of solid radioactive waste (Fig. 1). The wastes range from rubber gloves and glassware to parts of obsolete buildings and equipment that cannet be decontaminated. They are buried in pits ranging in size from 9 to $30 \mathrm{~m}$ wide, 45 to $180 \mathrm{~m}$ long, and 4 to $10 \mathrm{~m}$ deep. The waste is placed in layers 1 to $2 \mathrm{~m}$ deep, and each layer is covered with approximately $0.5 \mathrm{~m}$ of crushed tuff. The pits are filled to. within $1 \mathrm{~m}$ of the land surface, and covered with 1.5 to $2 \mathrm{~m}$ of crushed tuff. This final cover is slightly mounded above the original grade to encourage surface runoff. Some wastes are placed in vertical shafts, which range from 0.6 to $1.8 \mathrm{~m}$ in diameter, and up to $20 \mathrm{~m}$ deep.

Solid waste Pit 3 at Area $G$ was selected as the study location. It is typical of disposal pits at LASL (size and types of waste) and the surrounding terrain provided ready access to a drilling location. Further, there are no disposal shafts adjacent to Pit 3 ; possible lateral migration from wastes below the bottom of the pit is not a concern.

Pit 3 , excavated in 1963 , is $30 \mathrm{~m}$ wide, $160 \mathrm{~m}$ long, and about $8 \mathrm{~m}$ deep. Waste was placed in the pit in seven layers, which were separated by crushed or broken tuff. A final cover of $3 \mathrm{~m}$ of crushed tuff was placed over the waste. Waste disposal records indicate the quantities and location of waste in the pit. The inventory of radionuclides in the pit shows that the amount of ${ }^{3} \mathrm{H},{ }^{\circ} \mathrm{Sr}$, mixed activation and fission products is uncertain. A partial inventory shows 64 curies of ${ }^{200.200} \mathrm{Pu}$ and 58 curies of ${ }^{241} \mathrm{Am}$ when the pit was covered. "The total amounts probably do not exceed these figures by a factor of 2 . The records also show about 10 curies of uranium, primarily ${ }^{235} \mathrm{U}$ and ${ }^{230} \mathrm{U}$. The pit was filled and the final cover completed in 1966.

\section{B. Geology}

The surface and underlying rocks of the Pajarito Plateau are ash flows and ash falls of rhyolite tuff from the Jemez volcanic complex. ${ }^{5}$ The tuff is underlain by partially lithified sediments, basalt, and other volcanic rocks. The study location, in Area G, is near the eastern end of one of the mesas (Mesita del Buey) forming the Plateau. This mesa trends southeast, and is about $3.2 \mathrm{~km}$ long by $0.4 \mathrm{~km}$ wide. The surface slopes from an elevation of about $2100 \mathrm{~m}$ nea the western end to about $2010 \mathrm{~m}$ at its eastern end at Area $G$. It is bounded on the north and south by canyons cut 15 to $30 \mathrm{~m}$ below the mesa surface, and several small side drainages serate the edge of the mesa.

The sides of the mesa are vertical or near-vertical clifis, with steep slopes at their base. The ash-flow tuffs on the north-facing slopes of the canyon walls are generally covered with talus, while those on the south-lacing slopes are exposed. The surface of the mesa has a thin soil zone, up to a meter thick along the axis of the mesa and thinning toward the canyon rim where the tuff is exposed.

The Tshirege Member of the Bandelier Tuff forms the upper surface and underlies the mesa at Area

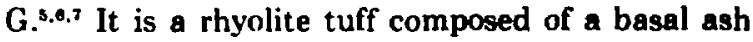
fall, followed by a series of ash fling. The Tshirege has been divided into several units, with the lower four present at Mesita del Buey (Fig. 2)." These units are typically nonwelded to moderately welded, and composed of quartz and sanidine crystals and crystal fragments, with some rock fragments of latite, rhyolite, and pumice in an ash matrix. The units are distinguished from each other by the degree of welding, color, and the size and relative 


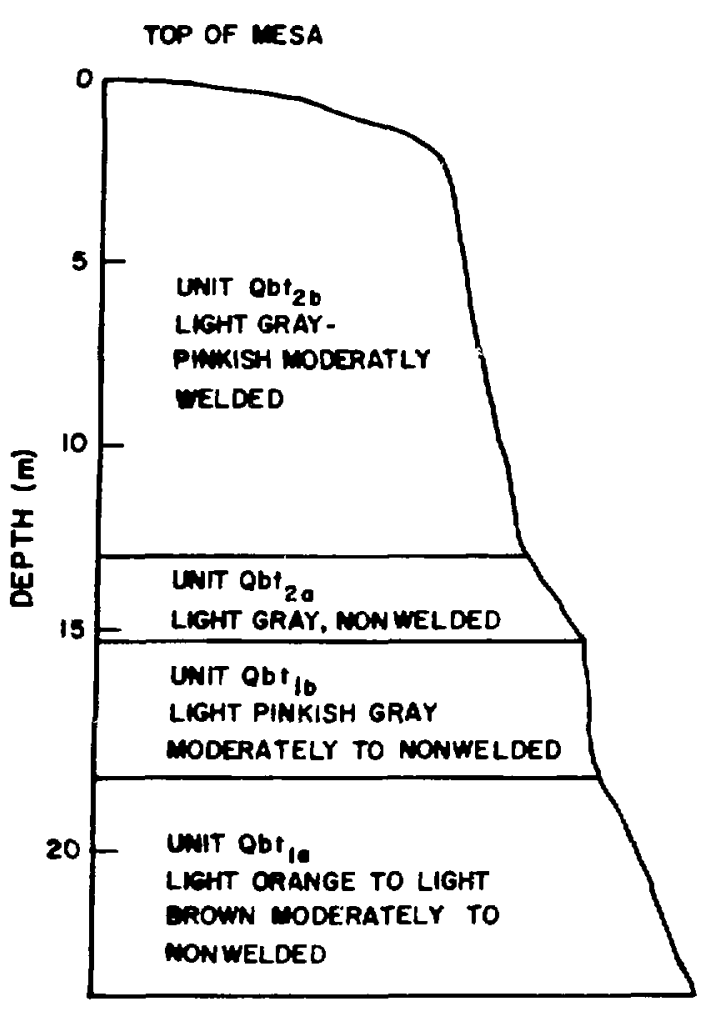

QOF = QUATERNARY BANDELIER TUFF

Fig. 2.

Geologic column showing stratigraphic units present at Mesita del Buey.

proportions of the crystal, rock and pumice fragments. The Bandelier Tuff contains numerous vertical or near vertical joints. These joints may be open or closed, or may have a filling of clay or caliche. Most of the jcints do not cross into formations underiying the Bandelier Tuff.

\section{Climatology}

The climate of the Pajarito Plateau is semiarid; annual precipitation ranges from 35 to $50 \mathrm{~cm}$ and potential evaporation is on the order of $150 \mathrm{~cm}$. Summer rainfall accounts for about $70 \%$ of the annual precipitation. The mean annual temperature is $9^{\circ} \mathrm{C}$ with extremes of $35^{\circ} \mathrm{C}$ in the summer and $-25^{\circ} \mathrm{C}$ in the winter.

\section{Hydrology}

The undisturbed soils have significant accumulations of clay at the soil-tuff contact." This clay is relatively impermeable, and retards the downward movement of infiltrated precipitation. As a result, the underlying tuff is quite dry, with moisture contents usually ranging from 2 to $5 \%$ by volume below a few meters.

The hydrologic characteristics of the undisturbed tuff vary with the degree of induration. The tuff has a saturated hydraulic conductivity on the order of $10^{-3} \mathrm{~cm} / \mathrm{min}$, and the conductivity decreases rapidly with decreasing water content. ${ }^{30}$ At a water content of $5 \%$ by volume, the hydraulic conductivity of the tuff is less than $10^{-8} \mathrm{~cm} / \mathrm{min},{ }^{10}$ and water movement is primarily in the vapor phase through the bulk tuff or open joints.

The hydrologic characteristics of disturbed crushed tuff, used as a final cover over the waste trenches, are comparable to those of undisturbed tuff. ${ }^{10}$ The hydraulic conductivity is somewhat higher because of greater effective porosity. Measurement of moisture distributions in the crushed tuff overlying buried waste show that the highest moisture contents ( $15-20 \%$ by volume) sccur at depths of less than $3 \mathrm{~m}$, with a continual decrease in moisture content below that depth. The high values are associated with spring snowmelt or summer thunderstorm activity, and within a few weeks the infiltrated water is returned to the atmosphere by evaporation or transpiration.?

There is no known perched water at Area G between the surface of the mesa and the main aquifer of the Lus Alamos area. The main aquifer (capable of municipal and industrial water supply) lies at a depth of $250 \mathrm{~m}$ below the surface of the mesa. The movement of water in the aquifer is trom the recharge area, an intermontane basin west of Los Alamos, to the Rio Grande where a part of the water is discharged to the river through seeps and springs. ${ }^{.1}$

Stream flow in the canyon north and south of Area $G$ is intermittent and occurs oniy during periods of heavy precipitation or spring snowmelt. The intermittent stream in the canyon to the south recharges a small body of water in the alluvium. The alluvium in the canyon north of Area $G$ does not contain any perched water because of the relatively small amount of surface runoff in that drainage. 


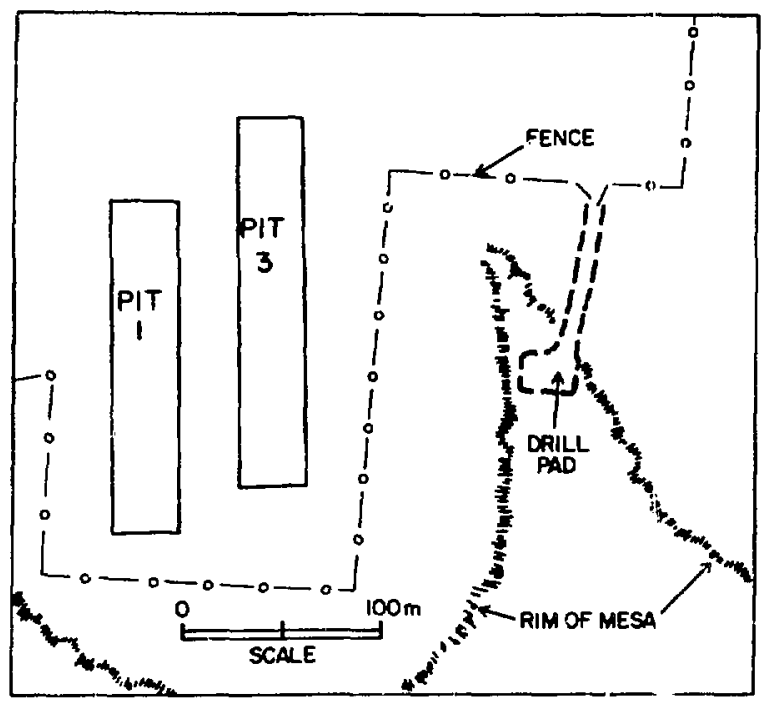

Fig. 3.

Southeastern part of Area $G$, showing location of waste pits and drill pad.

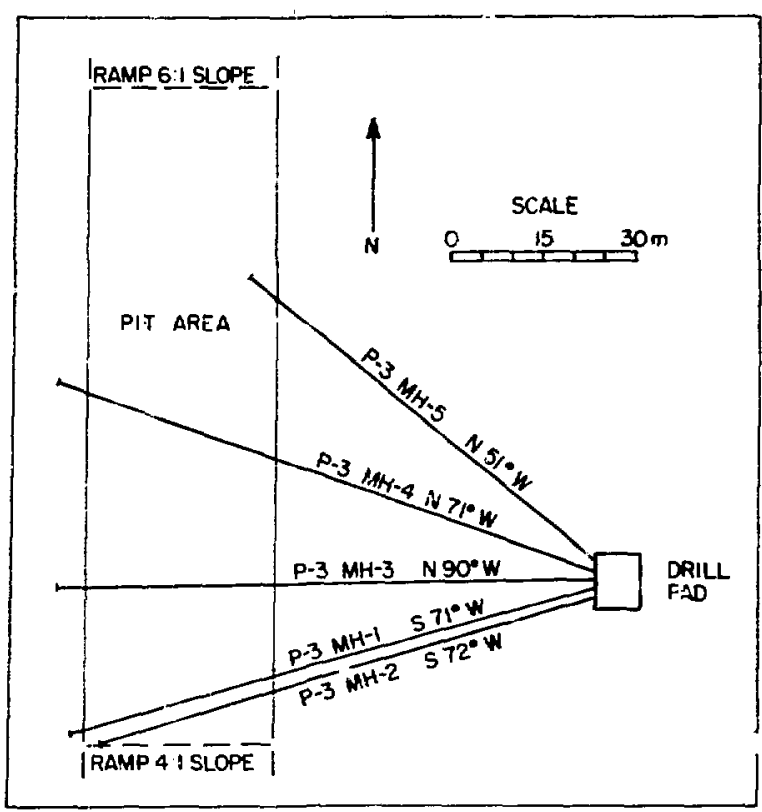

Fig. 4.

Orientation of core holes beneath Waste Pit 3, Area $G$.

\section{METHODS OF STUDY}

\section{A. Sample Collection}

For this study it was necessary to collect samples of the tuff from beneath Pit 3 for radiochemical analyses. Horizontal drilling to collect the semples was selected for two reasons.

1. Vertical holes would penetrate the wastes and possibly lead to cross-contamination of the samples.

2. Previous attempts at vertical coring in the tuff led to poor samplo recovery.

A drill pad was constructed in a small canyon east of the pit (Fig. 3). Five horizontal holes (Fig. 4) were cored under the pit using air as a cuttings carrier to avoid contamination of the core by drilling mud or water. During drilling operations the air and cuttings from the holes were discharged into a ciosed tank partly filled with water. The water retained most of the cuttings. The air from the tank was exhausted through high-velocity filters to rutain any remaining dust that might otherwise have been transmitted to the atmosphere. Water and cuttings from the tank were monitored for radioactive con-

tamination, as was the ambient air in the area. No contamination was detected in the water, cuttings, or air.

The completion data on each core hole were published in a summary report by Reynolds Electrical and Engineering Company, ${ }^{12}$ while the geologic desciption of cores from the holes was presented in a LASL publication."

The starting elevation of each hole was below the bottom of the pit, and the holes were oriented at initial angles slightly above the horizontal. As coring of a given hole progressed, the angle decreased because of gravitational rotation of the coring assembly and drill stem. (The coring angle and compass orientation were determined periodically with duwn-hole survey instruments.) At some distance from the drilling face, the hole angle passed through the horizonta!, and assumed a negative angle, plunging gently downward beneath the pit (Figs. 5 through 9). Thus, the core holes were not at a constant depth beneath the pit. Cores recovered for analyses ranged in depth from 0.0 to $3.4 \mathrm{~m}$ at the near (eastern) edge of the pit, to 3.1 to $7.2 \mathrm{~m}$ at the far (western) edge of the pit (Table I). 


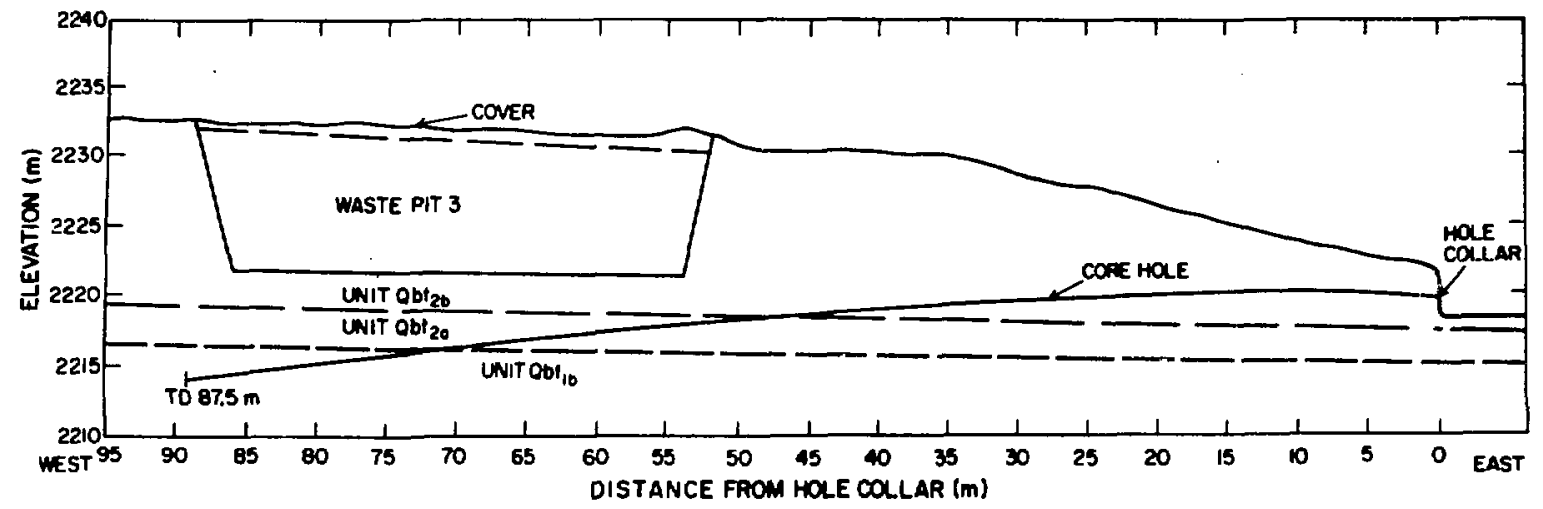

Fig. 5.

Cross section of the mesa showing the geologic unitu, pit 3, and the trace of core hole MH-1.

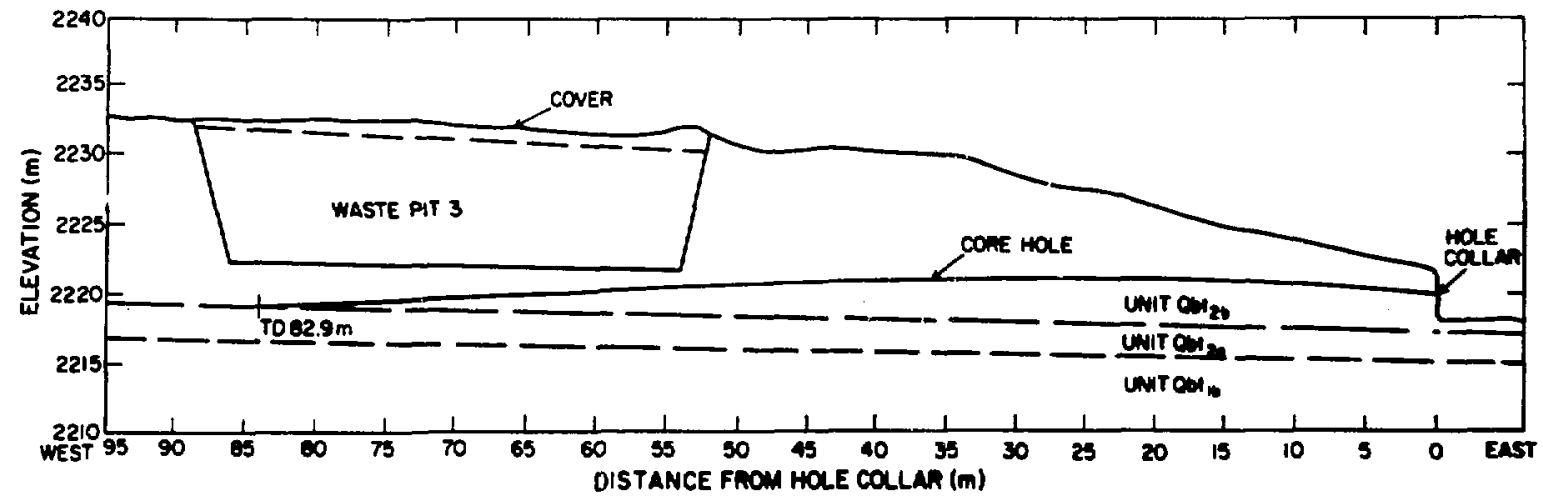

Fig. 6.

Cross section of the mesa showins geologic units, pit 3 , and the truce of core hole MH-2.

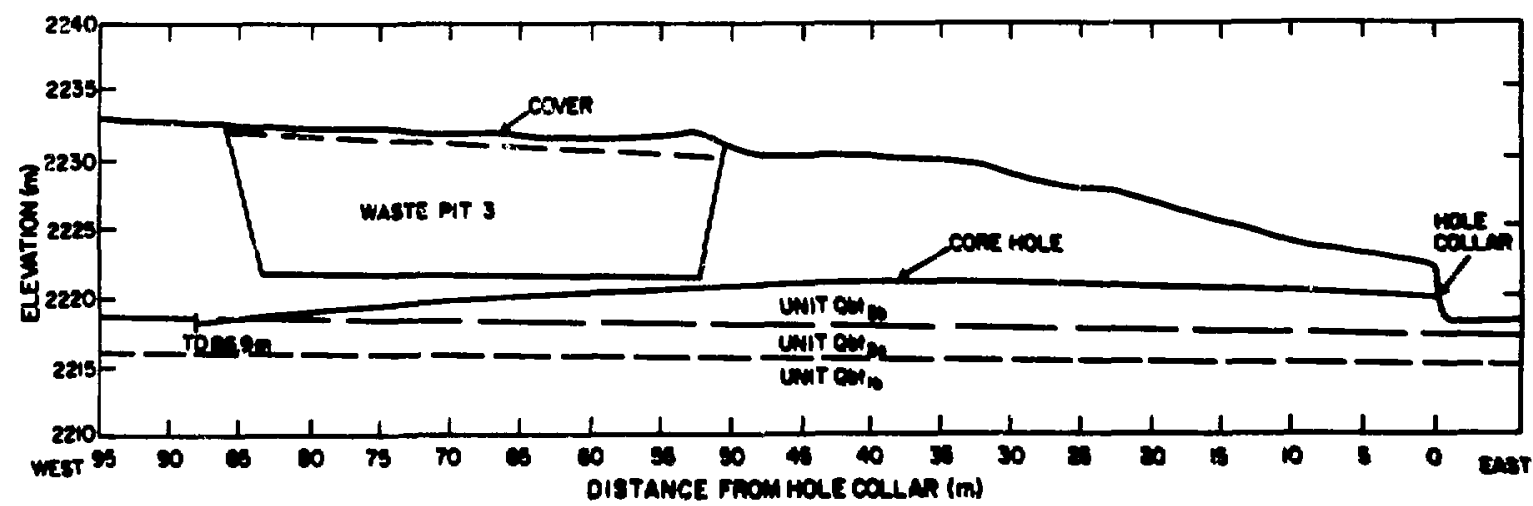

Fin. 7.

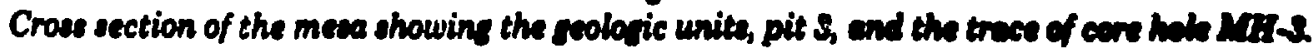




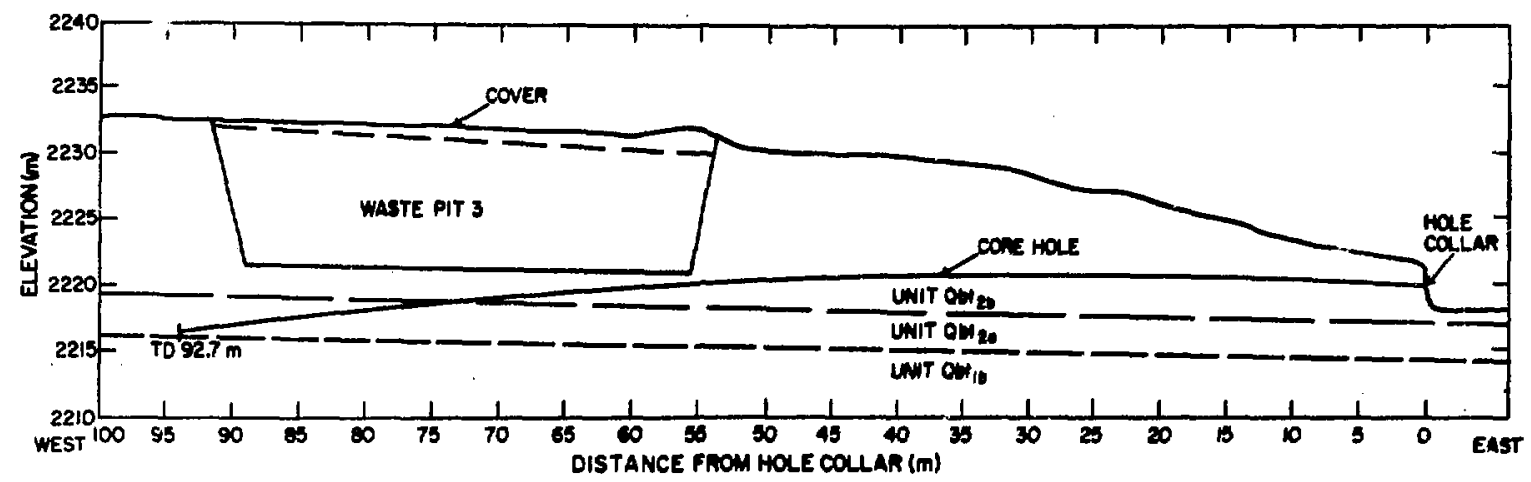

Fir. 8.

Cross section of the mesa showing geologic units, pit 3, and the trace of core hole MH-4.

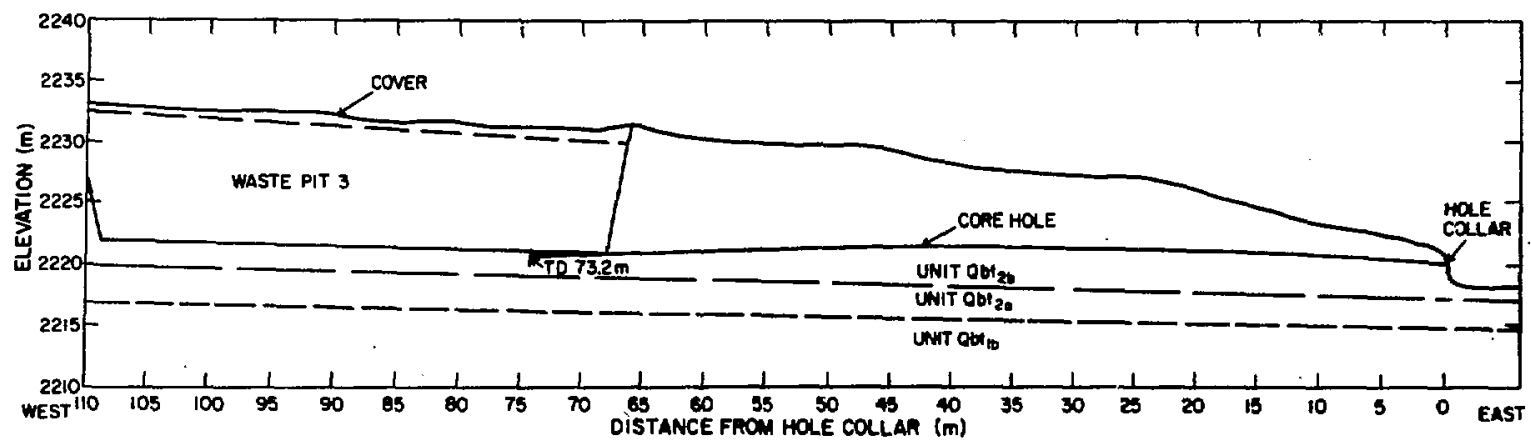

Fig. 9.

Cross section of the mesa showing geologic units, pit 3 , and the trace of core hole $M H-5$.

Three of the stratigraphic units of the Bandelier Tuff were penetrated by the core holes. All holes were initiated in Unit $2 \mathrm{~b}$. Core holes $\mathrm{MH}-2$ and $\mathrm{MH}$. 5 were completed in Unit $2 \mathrm{~b}$, holes $\mathrm{MH}-3$ and $\mathrm{MH}-4$ were completed in the upper part of Unit $2 \mathbf{a}$, and hole MH-1 was completed in Unit 1b. The recovery for a given core run varied from 37 to $100 \% .{ }^{19}$ As the core was logged, samples were collected at intervals of about every $1.5 \mathrm{~m}$ from the collar to within $5.5 \mathrm{~m}$ of the pit, and at intervals of about every $0.3 \mathrm{~m}$ from that point to the end of the hole."

\section{B. Radiochemical Analyses}

The core samples were analyzed for gross alpha, gross beta, ${ }^{20} \mathrm{Sr},{ }^{234} \mathrm{Pu},{ }^{238,200} \mathrm{Pu},{ }^{211} \mathrm{Am},{ }^{137} \mathrm{Cs}$ and total uranium. The following is a brief description of analytical methods. Detailed methods of analyses are presented in LA-7263-MS.'

The tuff cores were dried, ground, and sieved through No. $12(\sim 1.7 \mathrm{~mm})$ screazs. Separate aliquots of the prepared tuffi were taken for each analysis. Tuff for gross alpha and gross beta analyses was leached with hot acid and the leachate evaporated onto a stainless steel planchet before counting in a thin window, dual gas pror tional counter. Analytical results for gross alpha are reported with respect to ${ }^{2 m} \mathrm{Pu}$ as a standard, and for gross beta with respect to ${ }^{\text {}} \mathrm{Sr}-{ }^{\infty} \mathrm{Y}$ as a standard. Aliquots of tuff for ${ }^{20} \mathrm{Pu}$ and ${ }^{20,200} \mathrm{Pu}$ anulyses were spiked with ${ }^{243} \mathrm{Pu}$ to determine recovery percentages, while for ${ }^{21} \mathrm{Am}$ the aliquots were spiked with ${ }^{\mathrm{N}} \mathrm{Am}$. The $\mathrm{Pu}$ and $\mathrm{Am}$ were isolated by ion exchange, electroplated on a stainless steel disk, and counted on an alpha spectrometer. Aliquots of tuff for ${ }^{37} \mathrm{Ca}$ 


\section{TABLE I}

\section{HOLE LENGTH AND DEPTH BELOW PIT AT NEAR AND FAR EDGE}

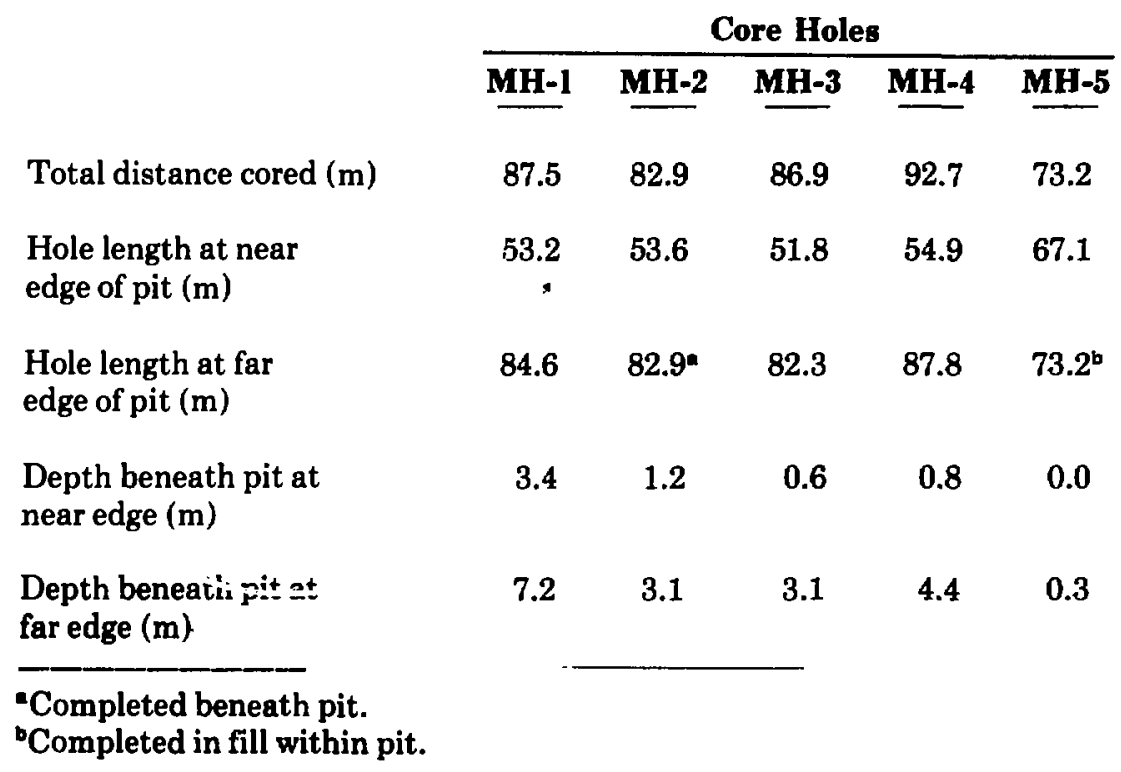

analyses were counted directly with a $\mathrm{Ge}(\mathrm{Li})$ detector, coupled with a multichannel analyzer. Tuff for ${ }^{\circ} \mathrm{Sr}$ analyses was dissolved with acid. The sample was extracted with HDEHP to remove the "0Y daughter and any interfering radionuclides. Stable $\mathrm{Y}$ was added as a chemical carrier. After allowing the ${ }^{\circ} \mathrm{Y}$ to re-equilibrate with the ${ }^{\circ} \mathrm{Sr}$, the sample was re-extracted, the $Y$ purified, and the sample counted on a gas proportional counter. Aliquots of tuff for total uranium analyses were irradiated by epithermal neutrons in a nuclear reactor and then counted with a $\mathrm{Ge}(\mathrm{Li})$ gamma ray spectrometer.

The minimum detection limits (MDL) for gross alpha and gross beta activity are 0.8 and $0.03 \mathrm{pCi} / \mathrm{g}$, respectively. The $\mathrm{MDL}$ for ${ }^{137} \mathrm{Cs}$ is $0.5 \mathrm{pCi} / \mathrm{g}$; for ${ }^{236} \mathrm{Pu},{ }^{230.240} \mathrm{Pu}$ and ${ }^{211} \mathrm{Am}, 0.005 \mathrm{pCi} / \mathrm{g}$; for ${ }^{20} \mathrm{Sr}, 1.0$ $\mathrm{pCi} / \mathrm{g}$; and for total uranium, $0.4 \mu \mathrm{g} / \mathrm{g}$.

\section{RESULTS AND DISCUSSION}

\section{A. Strategy}

The Bandelier Tuff contains naturally-occurring radionuclides, which emit alpha and/or beta radiation, including uranium. The presence of gross alpha, gross beta or uranium concentrations above expected background values would indicate possible migration of radionuclides from the waste pit to the underlying tuff. Further, elevated values in samples from beneath the pit compared with those from beside the pit, would be an additional indication of migration from the pit. Detection of the artificially produced radionuclides, ${ }^{20} \mathrm{Sr},{ }^{237} \mathrm{Cs},{ }^{200} \mathrm{Pu},{ }^{200,200} \mathrm{Pu}$, and ${ }^{241} \mathrm{Am}$, would indicate migration from either the waste in the pit, or from surface deposition of fallout from atmospheric tests. 
NATURAL AND FALLOUT CONCENTRATIONS OF RADIOACTIVITY AND RADIONUCLIDES IN REGIONAL SOILS AND SEDIMENTS (Concentrations in $\mathrm{pCl} / \mathrm{s}$ except as noted)

Gross Alpha
Gross Beta
${ }^{m r} \mathrm{Cs}$
${ }^{m} \mathrm{Pu}$
${ }^{m} \mathrm{Pu}$
$\mathrm{m}$

- $\mu \mathrm{g} / \mathrm{g}$.
Concentrations of man-made radionuclides occurring in surface soils and sediments have been determined for the period 1974-1978 in the area surrounding LASL, and are presented in Table II. 'The natural uranium content of the tuff varies from unit to unit. ${ }^{14}$ Concentrations measured in samples from outcrops are summarized in Table III. The data in Tables II and III are included for comparison with the analytical results for samples collected adjacent to and under the pit.

\section{B. Analytical Results}

The analytical results for samples from the core holes are summarized in Tables IV through VIII. Shown in the tables are the minimum, maximum, mean $(\bar{x})$, and twice the standard deviation (2S) for the number of analyses made in each core hole. The MDL for each analysis is shown in the respective table. The \pm value following the minimum and maximum values is the analtyical errors (1S) associated with that particular analysis. In order to conclude, at the $95 \%$ confidence level, that a particular radionuclide is present in a sample, the reported value minus twice the analytical error must exceed the stated MDL. If the reported value minus twice the analytical error is less than MDL, it can only be

\section{URANIUM CONCENTRATIONS IN OUTCROP \\ SAMPLES OF BANDELIER TUFF \\ (concentration, $\mu \mathrm{s} / \mathrm{s}$ )}

$\begin{array}{ccccc}\text { Unit } & \text { Min } & \text { Max } & \overline{\underline{x}} \\ & & & & \\ 2 \mathrm{~b} & 3.9 & 6.3 & 5.0 \\ 2 \mathrm{a} & 4.9 & 8.2 & 7.1 \\ 1 \mathrm{~b} & 7.2 & 8.2 & 7.8\end{array}$

concluded, at the $95 \%$ confidence level, that the radionuclide was not detected in the sample at concentrations above the MDL.

Each set of analyses is grouped according to the core holes from which the samples were collected. The analyses are further divided into those samples adjacent to the pit, and those samples underlying the pit. Data that might reflect naturally-occurring radioactivity (gross alpha, gross beta and uranium) were further subdivided into those samples from Unit $2 b$, Unit $2 a$, and Unit $1 b$. Unit $1 b$ was encountered only in core hole MH-1 (Fig. 5).

A total of 354 samples were analyzed for gross alpha and gross beta (Tables IV and V). Of these, 191 samples were from under the pit, and 165 samples were from the area adjacent to the pit. All measured concentrations were above the minimum detection limits.

A total of 107 samples from the five core holes were analyzed for total uranium (Table VI). These included all samples showing alpha activity substantially above the mean value. Fifty-eight of the samples were from the area adjacent to the pit, while the remaining 49 samples were from under the pit. All measured concentrations were above the minimum detection limits.

A total of 43 analyses were made for ${ }^{13} \mathrm{Cs}$ from samples from the five holes. Of these, 11 were from the area adjacent to the pit, and 32 were from under the pit (Table VII). The ${ }^{137} \mathrm{Cs}$ concentrations were at or below the MDL of $0.50 \mathrm{pCi} / \mathrm{g}$.

Forty-four samples from the five core holes were analyzed for ${ }^{235} \mathrm{Pu}$ and ${ }^{230.240} \mathrm{Pu}$ (Table VII). Of the 14 samples, 11 were from the area adjacent to the pit 
TABLE IV

\section{GROSS ALPHA ACTIVITY IN SAMPLES FROM CORE HOLES ADJACENT TO AND UNDER PIT 3 (concentrations in $\mathrm{pCl} / \mathrm{s}$ )}

\begin{tabular}{|c|c|c|c|c|c|}
\hline & $\begin{array}{c}\text { No. of } \\
\text { Analyses }\end{array}$ & Min & Max & $\mathbf{x}$ & $2 \sigma$ \\
\hline \multicolumn{6}{|c|}{ Adjacent to Pit } \\
\hline \multicolumn{6}{|c|}{ Unit 2b } \\
\hline MH-1 & 22 & $2.0 \pm 1.0$ & $5.6 \pm 2.4$ & 3.5 & 2.0 \\
\hline MH-2 & 27 & $1.9 \pm 1.0$ & $5.7 \pm 2.4$ & 3.0 & 1.8 \\
\hline MH-3 & 18 & $1.9 \pm 1.0$ & $5.1 \pm 2.2$ & 2.7 & 2.0 \\
\hline MH-4 & 21 & $2.0 \pm 1.0$ & $3.9 \pm 1.6$ & 2.8 & 1.0 \\
\hline MH-5 & 65 & $1.6 \pm 1.0$ & $4.7 \pm 2.0$ & 2.9 & 1.2 \\
\hline \multicolumn{6}{|l|}{ Unit 2a } \\
\hline MH-1 & 12 & $2.9 \pm 1.4$ & $8.7 \pm 3.6$ & 4.0 & 3.2 \\
\hline \multicolumn{6}{|l|}{$\begin{array}{c}\text { Under Pit } \\
\text { Unit } 2 b\end{array}$} \\
\hline MH-2 & 51 & $2.6 \pm 1.2$ & $6.4 \pm 2.8$ & 4.3 & 2.0 \\
\hline MH-3 & 52 & $2.1 \pm 1.1$ & $6.1 \pm 2.6$ & 3.8 & 1.8 \\
\hline MH-4 & 37 & $2.6 \pm 1.2$ & $8.3 \pm 3.4$ & 3.6 & 2.0 \\
\hline MH-5 & 5 & $2.6 \pm 1.2$ & $3.3 \pm 1.6$ & 3.0 & 0.6 \\
\hline \multicolumn{6}{|l|}{ Unit 2a } \\
\hline MH-1 & 14 & $3.2 \pm 1.4$ & $5.5 \pm 2.4$ & 4.3 & 1.2 \\
\hline MH-4 & 18 & $2.6 \pm 1.2$ & $5.6 \pm 2.4$ & 3.8 & 2.0 \\
\hline \multicolumn{6}{|l|}{ Unit 1b } \\
\hline MH-1 & 12 & $7.3 \pm \mathbf{3 . 0}$ & $13.0 \pm 6.0$ & 9.7 & 4.4 \\
\hline
\end{tabular}

Note: MDL gross alpha $0.8 \mathrm{pCi} / \mathrm{g}$, referenced to ${ }^{20 \mathrm{Pu}}$ as standard.

and 33 were from the area under the pits. All analyses were below the MDL of $0.005 \mathrm{pCi} / \mathrm{g}$.

Forth-three samples from the five core holes were analyzed for ${ }^{241} \mathrm{Am}$ (Table VIII). Of the 43 samples, 13 were from the area adjacent to the pit and 30 were from the area under the pit. The analyses were below the $\mathrm{MIDL}$ of $0.005 \mathrm{pCi} / \mathrm{g}$.

Forty-three samples from the five core holes were analyzed for ${ }^{90} \mathrm{Sr}$ (Table VIII). Of the 43 samples, 11 were from the area adjacent to the pit and 32 were from under the pit. All the analyses were below the MDL of $1.0 \mathrm{pCi} / \mathrm{g}$.

\section{Discussion}

Gross alpha, gross beta, and uranium concentrations in the samples were all above the minimum detection limits. For each type of analysis, a composite of the sample analyses from all holes penetrating a particular unit under the pit was compared statistically with a composite of analyses for samples in the same unit in the area adjacent to the pit. Further, the analyses were grouped according to geologic unit and compared with each other. All comparisons were made at a $95 \%$ confidence level.

The comparison of results showed no significant differences in gross alpha, gross beta, or uranium concentrations in samples from under the pit compared with those away from the pit for Units $2 a$ and 2b. Unit 1 b was not encountered in the area away from the pit because of its stratigraphic position. The comparisons did show differences in gross alpha, gross beta, and uranium concentrations between units; results for $2 a$ and $2 b$ were similar, 


\section{TABLE V}

\section{GROSS BETA ACTIVITY IN SAMPLES FROM CORE HOLES ADJACENT TO AND UNDER PIT 3 (concentrations in pCV/c)}

\begin{tabular}{|c|c|c|c|c|c|}
\hline & $\begin{array}{c}\text { No. of } \\
\text { Analyses }\end{array}$ & Min & Max & $\underline{x}$ & $\underline{2 \sigma}$ \\
\hline \multicolumn{6}{|c|}{$\begin{array}{l}\text { Adjacent to Pit } \\
\text { Unit } 2 b\end{array}$} \\
\hline MH-1 & 22 & $1.6 \pm 0.6$ & $6.1 \pm 1.4$ & 3.5 & 2.2 \\
\hline MH-2 & 27 & $0.8 \pm 0.6$ & $3.5 \pm 1.0$ & 2.0 & 1.4 \\
\hline MH-3 & 18 & $1.1 \pm 0.4$ & $5.2 \pm 1.2$ & 2.2 & 1.3 \\
\hline MH-4 & 21 & $1.1 \pm 0.6$ & $3.8 \pm 1.0$ & 1.9 & 1.6 \\
\hline MH-5 & 65 & $0.7 \pm 0.6$ & $3.7 \pm 1.0$ & 1.8 & 1.2 \\
\hline \multicolumn{6}{|l|}{ Unit 2a } \\
\hline MH-1 & 12 & $2.4 \pm 0.8$ & $6.2 \pm 1.4$ & 3.8 & 2.4 \\
\hline \multicolumn{6}{|l|}{ Under Pit } \\
\hline \multicolumn{6}{|l|}{ Unit 2b } \\
\hline MH-2 & 51 & $-0.5 \pm 0.4$ & $5.0 \pm 1.2$ & 2.8 & 1.8 \\
\hline MH-3 & 52 & $1.3 \pm 0.6$ & $6.3 \pm 1.4$ & 2.8 & 2.0 \\
\hline MH-4 & 37 & $1.4 \pm 0.6$ & $5.1 \pm 1.2$ & 2.4 & 1.8 \\
\hline MH-5 & 5 & $1.7 \pm 0.8$ & $3.0 \pm 0.8$ & 2.2 & 1.0 \\
\hline \multicolumn{6}{|l|}{ Unit 2a } \\
\hline MH-1 & 14 & $1.7 \pm 0.8$ & $4.3 \pm 1.0$ & 2.8 & 1.6 \\
\hline MH-4 & 18 & $1.1 \pm 0.6$ & $4.5 \pm 1.2$ & 2.3 & 1.8 \\
\hline \multicolumn{6}{|l|}{ Unit 1b } \\
\hline MH-1 & 12 & $4.2 \pm 1.2$ & $6.5 \pm 1.4$ & 5.4 & 2.2 \\
\hline
\end{tabular}

Note: MDL gross beta $0.03 \mathrm{pCi} / \mathrm{g}$, referenced to ${ }^{\circ 0} \mathrm{Sr}$ as standard.

but concentrations in Unit $1 \mathrm{~b}$ were significantly higher for all three types of analysis.

The analyses for man-made radionuclides indicate that such radionuclides are not present in the samples at concentrations above detection limits. The differences in gross alpha and gross beta concentrations between Unit $1 b$ and Unit $2 a$ or $2 b$ are substantially greater than the magnitude of the minimum detection limits. Thus, man-made radionuclides known to be in the pit cannot be responsible for these differences.

The differences in measured uranium concentra. tions between the various units are of the same magnitude as the measured differences in gross alpha concentrations. Thus, the elevated concentra- tion or uranium (an alpha emitter) in Unit $1 \mathrm{~b}$ is considered to be the primary source of the higher gross alpha values for the unit. Other naturallyoccurring alpha emitters, such as those belonging to the thorium decay series, are known to be present in the tuff, ${ }^{15}$ and are also likely contributors to the elevated alpha values. Concentrations of uranium in out crop samples (Table III) are similar to those in samples from beneath and beside the pit in the respective units.

The pattern of elevated gross beta concentrations was similar to that for gross alpha and uranium, and could not be accounted for by measured concentrations of man-made beta emitters. However, tritium $\left({ }^{3} \mathrm{H}\right)$, a naturally-occurring beta emitter, is also a 
TABLE VI

\author{
TOTAL URANIUM IN SAMPLES FROM CORE HOLES \\ ADJACENT TO AND UNDER PIT 3 \\ (concentrations in $\mu \mathrm{g} / \mathrm{g}$ )
}

\begin{tabular}{|c|c|c|c|c|c|}
\hline & $\begin{array}{c}\text { No. of } \\
\text { Anaiyses }\end{array}$ & Min & $\mathbf{M a x}$ & $\mathbf{x}$ & $2 \sigma$ \\
\hline \multicolumn{6}{|c|}{ Adjacent to Pit } \\
\hline \multicolumn{6}{|c|}{ Unit $2 b$} \\
\hline $\mathrm{MH}-\mathrm{I}$ & 9 & $4.4 \pm 1.0$ & $5.0 \pm 1.0$ & 4.7 & 0.4 \\
\hline $\mathrm{MH}-2$ & 11 & $4.5 \pm 1.0$ & $5.0 \pm 1.0$ & 4.7 & 0.3 \\
\hline MH-3 & 10 & $4.8 \pm 1.0$ & $5.2 \pm 1.0$ & 4.9 & 0.3 \\
\hline $\mathrm{MH}-4$ & 10 & $4.3 \pm 1.0$ & $4.8 \pm 1.0$ & 4.6 & 0.4 \\
\hline MH-5 & 16 & $4.5+1.0$ & $6.2 \pm 1.2$ & 4.9 & 0.8 \\
\hline \multicolumn{6}{|l|}{ Unit $2 a$} \\
\hline MH-1 & 2 & $4.7 \pm 1.0$ & $5.0 \pm 1.0$ & 4.8 & 0.4 \\
\hline \multicolumn{6}{|l|}{ Under Pit } \\
\hline \multicolumn{6}{|l|}{ Unit 2b } \\
\hline MH-2 & 9 & $4.1 \pm 0.8$ & $5.4 \pm 1.0$ & 4.8 & 0.9 \\
\hline $\mathrm{MH}-3$ & 9 & $4.5 \pm 1.0$ & $5.3 \pm 1.0$ & 4.7 & 0.5 \\
\hline $\mathrm{MH}-4$ & 4 & $4.7 \pm 1.0$ & $5.5 \pm 1.0$ & 5.0 & 0.7 \\
\hline MH-5 & 2 & $5.0 \pm 1.0$ & $5.9 \pm 1.2$ & 5.4 & 1.3 \\
\hline \multicolumn{6}{|l|}{ Init 2a } \\
\hline MH-1 & 7 & $4.9 \pm 1.0$ & $5.3 \pm 1.0$ & 5.1 & 0.1 \\
\hline $\mathrm{MH}-3$ & 1 & -.. & $5.1 \pm 1.0$ & 5.1 & 1.0 \\
\hline $\mathrm{MH}-4$ & 7 & $4.5 \pm 1.0$ & $5.3 \pm 1.0$ & 5.0 & 0.5 \\
\hline \multicolumn{6}{|l|}{ Unit (b) } \\
\hline MH-1 & 10 & $6.7 \pm 1.4$ & $8.6 \pm 1.8$ & 7.4 & 1.2 \\
\hline
\end{tabular}

Note: Total uranium MDL, $0.4 \mathrm{mg} / \mathrm{g}$.

known contaminant in the waste pit, primarily as tritiated water (HTO). The possible migration of tritium was not investigated in this study because the cores were obtained by drilling with air. Tritiated water vapor in the air would thus be mixed with any tritiated water in the core, rendering useless any data on tritium content of the samples.

The movement of tritium (as tritiated water vapor) from disposal pits and shafts has been documented. ${ }^{16,17}$ The tritiated water is incorporated in the natural flow of moisture in the tuff. This migration appears to be due primarily to the movement of water vapor through the open joints and fractures of the tuff. The movement through the bulk of the tuff is restricted, but is greater in zones of higher effective porosity.
It is thus feasible that tritium, while not specifically analyzed for, contributed to the elevated gross beta concentrations observed in Unit 1b. Only qualitative interpretations of possible tritium concentrations are possible; the technique used for gross beta determination is very imprecise for measurement of tritium concentrations. However, several observations argue against the possibility that the observed gross beta variations resulted from tritium in the samples. The concentration of potassium (and the associated ${ }^{\circ} \mathrm{K}$, a natural beta emitter) vary by a factor of two among units. ${ }^{13}$ It was previously noted that concentrations of uranium and thorium (and their associated decay chains) vary between Units $1 b$ and $2 a$ or $2 b$. Both decay chains contain numerous beta emitters, which would contribute to 
TABLE VII

\section{CESIUM AND PLUTONIUM IN SAMPLES FROM CORE HOLES ADJACENT TO AND UNDER PIT 3 \\ (concenurations in $\mathrm{MC} / \mathrm{C}$ )}

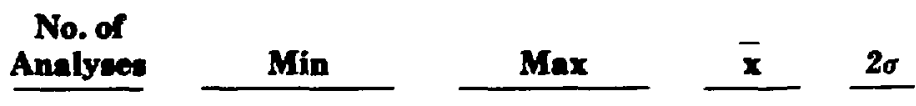

mas

Adjacent to Pit

MH-1

MH-2

MH-3

MH-4

MH-5

$\begin{array}{lr}2 & -0.10 \pm 0.40 \\ 2 . & -0.10 \pm 0.80 \\ 2 & 0.03 \pm 0.20 \\ 2 . & 0.00 \pm 0.16 \\ 2 & -0.03 \pm 0.06\end{array}$

$0.20 \pm 0.60$

0.05

0.42

$0.00 \pm 0.40$

$-0.05$

0.14

$0.30 \pm 0.80$

0.11

0.32

$0.06 \pm 0.16$

0.03

0.08

$0.04 \pm 0.04$

0.01

0.10

Under Pit

MH-1

MH-2

MH-3

MH-4

MH-5

$\begin{array}{rr}11 & -0.06 \pm 0.36 \\ 7 & :-0.15 \pm 0.60 \\ 6 & -0.03 \pm 0.12 \\ 6 & -0.05 \pm 0.40 \\ 2 & -0.17 \pm 0.40\end{array}$

$0.50 \pm 1.20$
$0.20 \pm 0.80$
$0.30 \pm 0.40$
$0.04 \pm 0.40$
$-0.07 \pm 0.12$

0.09

0.36

f.03 0.26

$0.08 \quad 0.24$

0.010 .08

$-0.12$

0.14

2an

Adjacent to Pit

MH-1

MH-2

MH-3

MH-4

MH-5

$\begin{array}{lr}3 & -0.003 \pm 0.006 \\ 2 & -0.002 \pm 0.002 \\ 2 & -0.001 \pm 0.001 \\ 2 & -0.001 \pm 0.001 \\ 2 & 0.001 \pm 0.002\end{array}$

$0.001 \pm 0.008$

$0.000 \pm 0.002$

$-0.003$

0.004

$0.000 \pm 0.002$

$-0.001$

0.002

$0.001 \pm 0.002$

$-0.000$

0.000

$0.001 \pm 0.010$

0.002

0.001

0.000

Under Pit

MH-1

MH-2

MH-3

MH-4

MH-5

$\begin{array}{rr}13 & -0.003 \pm 0.003 \\ 6 & -0.001 \pm 0.002 \\ 5 & -0.001 \pm 0.001 \\ 6 & -0.002 \pm 0.002 \\ 2 & -0.001 \pm 0.002\end{array}$

$0.001 \pm 0.002$

0.000

0.002

$0.001 \pm 0.008$

0.002

$0.000 \pm 0.002$

0.000

0.008

$0.000 \pm 0.002$

$-0.001$

0.000

$0.000 \pm 0.004$

0.000

0.002

smu

Adjacent to Pit

MH-1

MH-2

MH-3

MH-4

MH-5

$$
\begin{array}{r}
-0.004 \pm 0.006 \\
0.000 \pm 0.002 \\
-0.001 \pm 0.001 \\
-0.001 \pm 0.001 \\
-0.002 \pm 0.001
\end{array}
$$

$-0.001 \pm 0.002$

$-0.002$

0.004

$0.001 \pm 0.002$

$0.000 \pm 0.002$

0.001

0.000

$0.000 \pm 0.002$

$0.000 \quad 0.002$

$-0.001 \pm 0.006$

0.000

0.002

$\begin{array}{ll}-0.001 & 0.002\end{array}$

Under Pit

MH-1

MH-2

MH-3

MH-4

MH-5

6

$$
\begin{aligned}
& -0.001 \pm 0.003 \\
& -0.002 \pm 0.003 \\
& -0.001 \pm 0.002 \\
& -0.002 \pm 0.002 \\
& -0.001 \pm 0.003
\end{aligned}
$$

$0.003 \pm 0.003$

0.000

0.000

$0.002 \pm 0.010$

0.000

$0.003 \pm 0.004$

0.000

$0,0,01 \pm 0.002$

$-0.002$

0.002

0.002

0.004

$-0.003 \pm 0.006$

0.002

0.002 
TABLE VIII

\section{AMERICIUM AND STRONTIUM IN SAMPLES FROM CORE HOLES ADJACENT TO AND UNDER PIT 3 \\ (concentrations in $\mathrm{pCV} / \mathrm{s}$ )}

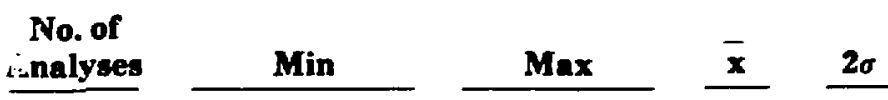

$\begin{array}{crrrrr}\begin{array}{c}\text { '41 Am } \\ \text { Adjacent to Pit }\end{array} & & & & & \\ \text { MH-1 } & 3 & 0.000 \pm 0.002 & 0.001 \pm 0.002 & 0.000 & 0.002 \\ \text { MH-2 } & 3 & 0.000 \pm 0.002 & 0.001 \pm 0.002 & 0.000 & 0.002 \\ \text { MH-3 } & 3 & 0.001 \pm 0.002 & 0.002 \pm 0.006 & 0.001 & 0.002 \\ \text { MH-4 } & 2 & 0.000 \pm 0.002 & 0.003 \pm 0.002 & 0.001 & 0.002 \\ \text { MH-5 } & 2 & 0.000 \pm 0.002 & 0.000 \pm 0.002 & 0.000 & 0.002 \\ & & & & & \\ \text { Under Pit } & & & & & \\ \text { MH-1 } & 12 & 0.000 \pm 0.002 & 0.004 \pm 0.004 & 0.000 & 0.002 \\ \text { MH-2 } & 5 & 0.000 \pm 0.002 & 0.001 \pm 0.004 & 0.001 & 0.002 \\ \text { MH-3 } & 5 & 0.000 \pm 0.002 & 0.003 \pm 0.006 & 0.001 & 0.002 \\ \text { MH-4 } & 6 & -0.002 \pm 0.006 & 0.002 \pm 0.002 & 0.000 & 0.002 \\ \text { MH-5 } & 2 & 0.000 \pm 0.002 & 0.000 \pm 0.002 & 0.000 & 0.000 \\ & & & & & \\ \text { mSr } & & & & & \\ \text { Adjacent to Pit } & & & & & \\ \text { MH-1 } & 2 & 0.40 \pm 0.20 & 0.50 \pm 0.20 & 0.45 & 0.14 \\ \text { MH-2 } & 2 & 0.00 . \pm 0.40 & 0.20 \pm 0.20 & 0.10 & 0.28 \\ \text { MH-3 } & 3 & 0.10 \pm 0.20 & 0.80 \pm 1.80 & 0.43 & 0.70 \\ \text { MH-4 } & 2 & 0.00 \pm 0.08 & 0.10 \pm 0.20 & 0.05 & 0.14 \\ \text { MH-5 } & 2 & 0.10 \pm 0.20 & 0.10 \pm 0.20 & 0.10 & 0.00 \\ & & & & & \\ \text { Under Pit } & & & & & \\ \text { MH-1 } & 12 & 0.02 \pm 0.20 & 0.40 \pm 0.20 & 0.24 & 0.44 \\ \text { MH-2 } & 7 & 0.05 \pm 0.20 & 0.20 \pm 0.20 & 0.15 & 0.32 \\ \text { MH-3 } & 6 & -0.03 \pm 0.40 & 0.40 \pm 0.20 & 0.14 & 0.36 \\ \text { MH-4 } & 5 & 0.00 \pm 0.20 & 0.10 \pm 0.20 & 0.06 & 0.10 \\ \text { MH-5 } & 2 & -0.10 \pm 0.20 & 0.20 \pm 0.20 & 0.05 & 0.42\end{array}$

Note: MDL for ${ }^{21} \mathrm{Am} 0.005 \mathrm{pCi} / \mathrm{g} ;{ }^{m} \mathrm{Sr}, 1.0 \mathrm{pCi} / \mathrm{g}$.

the observed differences. Finally, the elevated gross beta concentrations were observed in the lowest unit penetrated (1b), with lower concentrations in the overlying Units $2 a$ and $2 b$. If tritium in the waste pit were the source of the elevated gross beta concentrations, the concentrations would be highei im- mediately adjacent to the bottom of the pit. For these reasons, the possible presence of tritium in the samples is not considered to be the source of the observed differences in gross beta concentrations among stratigraphic units. Rather, these variations are attributed to natural beta emitters in the tuff. 


\section{SUMMARY AND CONCLUSIONS}

\section{A. Summary}

Solid radioactive wastes from LASL are disposed of by burial in pits excavated in rhyolite tuff at LASL disposal sites. The semiarid climate, coupled with relatively low permeabilities of soil and un. derlying tuff, restricts the downward movement of water within waste materials. This study was performed in an attempt to detect the migration of radionuclides in waste to the tuff immediately underlying a waste pit.

Waste Pit 3, used from 1963 to 1966 was selected as the study location. Disposal records identified the presence of ${ }^{3} \mathrm{H},{ }^{\circ} \mathrm{Sr}$, mixed activation and fission products, ${ }^{231,200} \mathrm{Pu},{ }^{241} \mathrm{Am}$, and uranium as contaminants in the waste.

The tuff at the study location has been divided into several stratigraphic units, distinguishable from each other by chemical and physical properties. The natural concentrations of uranium, as well as other natural radionuclides, vary from unit to unit.

In 1976, horizontal core holes were drilled in a fanshaped array beneath the disposal pit from a drill pad in an adjacent drainage. The depth of the core holes beneath the bottom of the pit varied from nearly zero to more than seven meters. Samples of tuff adjacent to and beneath the pit were analyzed for radionuclides known to be present in the pit, as well as for gross alpha and gross beta radiation. The analytical results from samples beneath the pit were compared statistically with those from samples from beside the pit. The analytical results we also grouped according to stratigraphic units, and comparisons were made between units and with outcrop data for the respective units.

\section{B. Concluaions}

The man-made radionuclides known to be present in the pit, ${ }^{10} \mathrm{Sr},{ }^{107} \mathrm{Cs},{ }^{200} \mathrm{Pu}$, ${ }^{200,200} \mathrm{Pu}$, and ${ }^{201} \mathrm{Am}$, were not present in the samples at concentrations above the minimum detection limits.

Gross alpha and gross beta radiation, as well as uranium, was detected in the samples. However, the tuff contains naturally-occurring radionuclides, including uranium. There are no statistically significant differences in the concentrations of gross alpha, gross beta, or uranium in samples from under the pit compared with those adjacent to the pit within respective stratigraphic units.

Uranium concentrations varied between stratigraphic units, but the mean values from the cores were statistically indistinguishable from concentrations measured in outcrops. Similar variability in gross alpha concentrations between units is attributed to the observed variability in uranium, as well as to other naturally-occurring radionuclides.

Gross beta variations were also obsarved between stratigraphic units. Tritium, a known contaminant in the waste pit and a weak beta emitter, was not analyzed for because of potential crosscontamination with atmospheric tritium. However, the pattern of beta variations (increasing downward from the pit) provides a strong argument that tritium from the pit is not the source of the observed variability. Rather, the variations are attributed to other naturally-occurring radionuclides.

Thirteen years elapsed between the initial use of the disposal pit and this investigation. The state of the waste containers in the pit is uncertain, but many were undoubtedly ruptured at the time of disposal through compaction by heavy earthmoving equipment. Further, much of the waste, including some contaminated soil, was not in containers. Thus most of the radionuclides in the pit can be assumed to be available for dissolution by moving soil moisture. The actual rates of such dissolution are not known.

The expected water flow velocities in the solid and crushed tuff, on the order of fractions of a $\mathrm{cm} /$ year, suggest that no migrating solutions would be detectable at depths of more than a few centimeters beneath the pit. That expectation is not contradicted by this study, in that no radionuclides were detected in the samples whose presence can be attributed to migration from the pit.

\section{ACKNOWLEDGMENTS}

This study would have been imposuible without the assistance of Ken Larkin and the drilling pereonnel from Reynolds Electrical and Engineering Company. All analytical work was performed or directed by the Environmental Studies Group H-8, at LASL. 
Their help is greatly appreciated. The statistical analyses were done by Willy Abeele, in the Environmental Science Group LS-6, at LASL. Without these analyses, the data collected by the study wovid have been very difficult to interpret. Finally, the authors are indebted to Ed Essington, also in LS-6, for his diligent and critical review of our initial draft.

\section{REFERENCES}

1. J. H. Abrahams, "Physical Properties and Movement of Water in the Bandelier Tuff, Los Alamos and Santa Fe Counties, New Mexico," U.S. Geol. Survey open-file report (1963).

2. J. H. Abrahams, J. E. Weir, and W. D. Purtymun, "Distribution of Moisture in Soil and Near-Surface Tuff on the Pajarito Plateau, Los Alamos County, New Mexico," U.S. Geol. Survey Prof. Paper 424 D (1961).

3. W. D. Purtymun and W. R. Kennedy, "Distribution of Moisture and Radicactivity in the Soil and Tuff at the Contaminated Waste Pit Near Technical Area 21, Los Alamos, New Mexico," U.S. Geol. Survey open-file report (1966).

4. M. A. Rogers, "History and Environmental Setting of LASL Near-Surface Land Disposal Facilities for Radioactive Wastes (Areas A, B, C, D, E, F, G, and T)," Los Alamos Scientific Laboratory report LA-6848-MS, Vols. 1 and 2 (1977).

5. R. L. Griggs, "Geology and Ground Water Resources of the Los Alamos Area, New Mexico," U.S. Geol. Survey Water-Supply Paper 1753 (1964).

6. W. D. Purtymun, "Geology and Hydrology of Area G, Mesita del Buey, Los Alamos County, New Mexico," U.S. Geol. Survey open-file report (1966).
7. W. D. Purtymun and W. R. Kennedy, "Geology and Hydrology of Mesita del Buey," Los Alamos Scientific Laboratory report LA-4660 (1971).

8. "Environmentaì Surveillance at Los Alamos During 1977," Los Alamos Scientific Laboratory report LA-7263-MS (1978).

9. J. W. Nyhan, L. W. Hocker, T. E. Calhoun, and D. L. Young, "Soil Survey of Los Alamos County," Los Alamos Scientific Laboratory report LA-6779-MS (1978).

10. M. L. Wheeler, W. J. Smith, A. F. Gallegos, "A Preliminary Evaluation of the Potential for Plutonium Release from Burial Grounds at Los Alamos Scientific Laboratory," Los Alamos Scientific Laboratory report LA-6694-MS (1977).

11. R. L. Cushman, "An Evaluation of Aquifer and Well Characteristics of Municipal Well Fields in Los Alamos and Guaje Canyons, Near Los Alamos, New Mexico," U.S. Geol. Survey Water-Supply Paper 1809-D (1965).

12. Reynolds Electric and Engineering Co., "Horizontal Monitoring Holes, Los Alamos, New Mexico, Completion Report," Contract E(26-1) 40 ERDA, October 1976.

13. W. D. Purtymun, M. L. Wheeler, and M. A. Rogers, "Geologic Description of Cores from Holes P-3 MH-1 through P-3 MH-5, Area G, Technical Area 54," Los Alamos Scientific Laboratory report LA-7308-MS (1978).

14. M. A. Rogers and B. W. Burton, "Trace Element Study of the Bandelier Tuff (Pleistocene), Pajarito Plateau, Los Alamos and Santa Fe Counties, North Central New Mexico," (in preparation).

15. B. W. Crowe, G. L. Linn, G. Heiken, M. L. Bevier, "Stratigraphy of the Bandelier Tuff in the Pajarito Plateau," Los Alamos Scientific Laboratory report LA-7225-MS (1978). 
16. W. D. Purtymun, "Underground Movement of Tritium from Solid-Waste Storage Shafts," Los Alamos Scientific Laboratory report LA-5286MS (1973).
17. M. L. Wheeler and J. L. Warren, "Tritium Containment after Burial of Contaminated Solid Wastes," Proceedings 23rd Conf. on Remote Systems Technology, San Francisco, California (1975). 